\title{
ANALISIS TINGKAT KESEHATAN BANK DENGAN METODE RGEC (STUDI KASUS PADA PT.BANK MUAMALAT Tbk) PERIODE 2012-2016
}

\author{
Zein Ghozali \\ Universitas Sjakhyakirti \\ Email:zein.ghozali75@gmail.com \\ Riri Hanifa \\ Universitas Sjakhyakirti \\ Email: ririhanifa0718@gmail.com \\ Mahdi Hendrich \\ Universitas Sjakhyakirti \\ Email:Mahdihendrich03@gmail.com
}

\begin{abstract}
This study aims to determine the level of health of PT Bank Muamalat Indonesia Tbk from 2012 to 2016, measured using the RGEC (Risk Profile, Good Corporate Governance, Earnings and Capital) approach. This bank Health Assessment is based on Bank Indonesia Regulation Number 13/1 / PBI / 2011. This type of research is a descriptive study with a quantitative approach. The Risk Profile variable is measured using the NPL ratio, Net Open Position (NOP) and LDR. Variables and measurements in this study consist of Risk Profile, Good Corporate Governance, Earning and Capital factors. The analysis showed that the health level of PT Bank Muamalat Indonesia Tbk in the period 2012 to 2016 was in the healthy category. Risk Profile indicators are categorized as Low to moderate positions during the 2012-2016 period. GCG indicators are categorized as Good during the study period. PT.BMI Tbk Earning Indicator is categorized as Less Healthy during 2012-2016. By using the CAR indicator, the researchers prove that PT Bank Muamalat Tbk has a good Capital factor, which is above the Bank Indonesia regulation of $8 \%$
\end{abstract}

Keywords: : Risk Profile, Good Corporate Governance, Earning, Capital

\section{Abstrak}

Penelitian ini bertujuan untuk mengetahui tingkat kesehatan PT.Bank Muamalat Indonesia Tbk periode 2012 sampai dengan 2016, diukur dengan menggunakan pendekatan RGEC (Risk Profile, Good Corporate Governance, Earnings dan Capital). Penilaian Kesehatan bank ini berdasarkan Peraturan Bank Indonesia Nomor 13/1/PBI/2011. Jenis Penelitian yang digunakan adalah penelitian deskriptif dengan pendekatan kuantitatif. Variabel Risk Profile diukur dengan menggunakan rasio NPL, Posisi Devisa Netto (PDN) dan LDR. Variabel dan pengukuran pada penelitian ini terdiri dari faktor Risk Profile, Faktor Good Corporate Governance, faktor Earning dan faktor Capital. Hasil analisis menunjukkan bahwa tingkat kesehatan PT.Bank Muamalat Indonesia Tbk pada periode 2012 sampai dengan 2016 dalam kategori sehat. Indikator Risk Profile dikategorikan pada posisi Low to moderate selama periode 2012-2016. Indikator GCG dikategorikan Baik selama periode penelitian. Indikator Earning PT.BMI Tbk dikategorikan Kurang Sehat selama periode 2012-2016. Dengan menggunakan indikator CAR, peneliti membuktikan bahwa PT.Bank Muamalat Tbk memiliki faktor Capital yang baik, yaitu diatas ketentuan Bank Indonesia sebesar 8\%.

Kata Kunci: Risk Profile, Good Corporate Governance, Earning, Capital

\section{Pendahuluan}

Menurut Undang-undang RI Nomor 10 tahun 1998 tentang Perbankan, Bank adalah badan usaha yang menghimpun dana dari masyarakat dalam bentuk kredit dan bentuk lainnya dalam rangka meningkatkan taraf hidup orang banyak. Didalam Undang-Undang tersebut mengatur:

a. Bank wajib memelihara tingkat kesehatan bank sesuai dengan ketentuan kecukupan modal, kualitas asset, kualitas manajemen, likuiditas, solvabilitas dan aspek lain yang 
berhubungan dengan usaha bank dan wajib melakukan kegiatan usaha sesuai dengan prinsip kehati-hatian.

b. Dalam memberikan kredit atau pembiayaan berdasarkan prinsip syariah dan melakukan kegiatan usaha lainnya, bank wajib menempuh cara-cara yang tidak merugikan bank dan kepentingan nasabah yang mempercayakan dananya kepada bank.

c. Bank wajib menyampaikan kepada BI segala keterangan dan penjelasan mengenai usahanya menurut tata cara yang ditetapkan oleh BI

d. Bank atas permintaan BI, wajib memberikan kesempatan bagi pemerikasaan bukubuku dan berkas-berkas yang ada padanya serta wajib memberikan bantuan yang diperlukan dalam rangka memperoleh kebenaran dari segala keterangan, dokumen dan penjelasan yang dilaporkan oleh bank yang bersangkutan.

e. Bank Indonesia melakukan pemerikasaan terhadap bank, baik secara berkala maupun setiap waktu apabila diperlukan, BI dapat menugaskan akuntan publik untuk dan atas nama bank Indonesia melaksanakan pemerikasaaan terhdap bank.

f. Bank wajib menyampaikan neraca, perhitungan laba rugi tahunan, dan penjelasannya, serta laporan berkala lainnya dalam waktu dan bentuk yang ditetapkan oleh BI.

Sejalan dengan kebutuhan tersebut diatas, Bank Indonesia kemudian menyempurnakan metode penilaian tingkat kesehatan bank umum. Penilaian terhadap kinerja bank tersebut diukur dalam beberapa indikator yaitu profil risiko, good corporate governance, earning (rentabilitas), capital (permodalan). Pedoman tersebut diatur selengkapnya dalam Peraturan Bank Indonesia Nomor 13/1/PBI/2011 tanggal 5 Januari 2011, tentang penilaian kesehatan bank umum..

PT.Bank Muamalat Indonesia Tbk adalah bank syariah pertama di Indonesia yang berdiri pada tanggal 1 November 1991. Pendirian PT.Bank Muamalat Indonesia digagas oleh Majelis Ulama Indonesia (MUI), Ikatan Cendikiawan Muslim Indonesia (ICMI), dan pengusaha muslim yang kemudian mendapat dukungan dari Pemerintah Republik Indonesia dan resmi beroperasi pada tanggal 2 Mei 1992.

Namun dimulai pada tahun 2016 PT. Bank Muamalat Indonesia Tbk yang dipimpin oleh Endi PR Abdurahman ini mulai menampakan tanda-tanda goyah. Berdasarkan laporan keuangan yang di publikasikan PT. Bank Muamalat Indonesia Tbk dan data dari OJK, PT. Bank Muamalat Indonesia Tbk telah mengalami kontraksi bisnis sejak mengalami pergantian top eksekutive saat ini. Di mulai dari penurunan laba secara drastis sampai 71,36 \% per Juni 2016, yaitu Rp106,54 Milyar menjadi Rp30,51 Milyar. YNPF gross naik tinggi sebesar 7,23\% dari tahun sebelumnya sebesar 4,93\% per Juni 2015. Indikator vital lainnya yang agak mengkwatirkan adalah penuruan CAR yang signifikan, per Mei 2106 di angka 11,71\% padahal pada Desember 2015 masih di level 12,36\%. Demikian halnya dengan modal juga anjlok dari Rp57,1 Trilyun menjadi Rp53,71 trilyun. (www.jakartasatu.com). Hal ini menunjukkan bahwa manajemen risiko dan Good Corporate Governance PT.Bank Muamalat Indonesia Tbk tidak berfungsi sebagaimana mestinya sehingga menumbulkan banyaknya kredit macet

Pada tahun 2014 PT. Bank Muamalat Indonesia telah mengoperasikan 457 outlet pelayanan yang mencakup kantor cabang, kantor cabang pembantu, kantor kas, maupun unit mobile branch serta 1,958 unit ATM muamalat. Namun pada akhir tahun 2016 
jumlah outlet layanan dan atm berkurang menjadi 363 outlet dan 1.337 atm (www.bankmuamalat.co.id)

Setelah mengetahui permasalahan-permasalahan diatas, penulis berminat untuk melakukan penelitian tingkat kesehatan pada PT. Bank Muamalat Indonesia Tbk dengan menggunakan metode RGEC PBI 13/1/PBI/2011. Penulis mengambil penelitian dengan judul "Analisis Tingkat Kesehatan Bank Dengan Menggunakan Metode RGEC (Studi Kasus Pada PT.Bank Muamalat Indonesia Tbk Periode 2012-2016)".

\section{Literature Review}

\subsection{Konsep Metode RGEC}

Berdasarkan Surat Edaran (SE) Bank Indonesia No.13/24/DPNP kriteria yang digunakan dalam penelitian ini menggunakan pendekatan metode RGEC, yaitu:

\section{Profil risiko (risk profile)}

Penilaian terhadap faktor profil risiko merupakan penilaian terhadap risiko inheren dan kualitas penerapan manajemen risiko dalam operasional Bank. Risiko yang wajib dinilai terdiri dari atas 8 (delapan) jenis risiko yaitu risiko kredit, risiko pasar, risiko likuiditas, risiko likuiditas, risiko operasional, risiko hukum,risiko stratejik, risiko kepatuhan dan risiko reputasi.

\section{a. Penilaian Risiko Inheren}

Penilaian risiko inheren merupakan penilaian atas risiko yang melekat pada kegiatan bisnis bank, baik yang dapat dikuantifikasikan maupun yang tidak berpotensi mempengaruhi posisi keuangan bank. Karakteristik risiko inheren bank ditentukan oleh faktor internal maupun ekternal, antara lain strategi bisnis, karakteristik bisnis, kompleksitas produk dan aktivitas bank, industri dimana bank melakukan kegiatan usaha serta kondisi makro ekonomi. Risiko Inheren antara lain:

\section{1) Risiko Kredit}

Risiko kredit adalah risiko akibat kegagalan debitur dan/atau pihak lain dalam memenuhi kewajiban kepada bank. Indikator yang digunakan dalampenelitian untuk mengukur risiko kredit, yaitu rasio Non Performing Loan (NPL).

\section{2) Risiko Pasar}

Risiko Pasar adalah risiko pada posisi neraca dan rekening administratiftermasuk transaksi derivatif, akibat perubahan dari kondisi pasar, termasuk risikoperubahan harga option. Dalam mengukur risiko pasar ini menggunakan indikatorPosisi Devisa Netto (PDN).

\section{3) Risiko Likuiditas}

Risiko Likuiditas adalah Risiko akibat ketidakmampuan bank untukmemenuhi kewajiban yang jatuh tempo dari sumber pendanaan arus kas, dan/ataudari aset likuid berkualitas tinggi yang dapat diagunkan, tanpa menggangguaktivitas dan kondisi keuangan bank. Risiko ini disebut juga Risiko likuiditaspendanaan (funding liquidity risk). Rasio ini juga merupakan indikator kerawanan dankemampuan dari suatu bank. Sebagian praktisi perbankan menyepakati bahwabatas aman dari loan to deposit rasio suatu bank adalah sekitar 80\%. Namun, batastoleransi berkisar antara 85\% sampai 100\% (Dendawijaya, 2003). 


\section{4) Risiko Operasional}

Risiko Operasional adalah risiko akibat ketidakcukupan dan atau tidak berfungsinya proses internal, kesalahan manusia, kegagalan sistem, dan atau adanya kejadian-kejadian ekternal yang mempengaruhi operasional bank.

\section{5) Risiko Hukum}

Risiko Hukum adalah risiko akibat tuntutan hukum atau kelemahan aspek yuridis. Risiko Hukum dapat bersumber antara lain dari kelemahan aspek yuridis yang disebabkan oleh lemahnya perikatan yang dilakukan oleh bank, ketiadaan dana atau perubahan peraturan perundang-undangan yang menyebabkan suatu transaksi yang telah dilakukan bank menjadi tidak sesuai dengan ketentuann yang akan ada, dan proses litigasi baik yang timbul dari gugatan pihak ketiga terhadap bank maupun bank terhadap pihak ketiga.

\section{6) Risiko Stratejik}

Risiko Stratejik adalah risiko akibat ketidaktepatan dalam pengambilan dan atau pelaksanaan suatu keputusan stratejik serta kegagalan dalam mengantisipasi perubahan lingkungan bisnis.

\section{7)Risiko Kepatuhan}

Risiko kepatuhan adalah risiko akibat bank tidak mematahi dan atau tidak melaksanakan peraturan perundang-undangann dan ketentuan yang berlaku. Risiko kepatuhan dapat bersumber antara lain dari perilaku hukum yakni perilaku aktivitas bank yang menyimpang atau melanggar dari ketentuan atau peraturan perundang-undangan yang berlaku dan perilaku organisasi yakni perilaku/aktivas bank yang menyimpang atau bertentangan dari standar yang berlaku secara hukum.

\section{8) Risiko Reputasi}

Risiko reputasi adalah risiko akibat menurunnya tingkat kepercayaan pemangku kepentingan (stakeholder) yang bersumber dari persepsi negatif terhadap bank. Dalam menilai profil risiko, bank wajib pula memperhatikan cakupan penerapan manajemen risiko bagi bank umum.

\section{Good Corporate Governance (GCG)}

Berdasarkan SEBI No.15/15/DPNP/2013 bank harus melakukan penilaiansendiri (self assessment) secara berkala yang paling kurang meliputi 11 (sebelas)Faktor Penilaian Pelaksanaan GCG yaitu: 1)pelaksanaan tugas dan tanggung jawab Dewan Komisaris;2) pelaksanaan tugas dan tanggung jawab Direksi;3) kelengkapan dan pelaksanaan tugas Komite;4) penanganan benturan kepentingan;5) penerapan fungsi kepatuhan;6) penerapan fungsi audit intern;7) penerapan fungsi audit ekstern;8) penerapan manajemen risiko termasuk sistem9) pengendalian intern;10) penyediaan dana kepada pihak terkait (related party) dan11) penyediaan dana besar (large exposures);12) transparansi kondisi keuangan dan non keuangan Bank,13) laporan pelaksanaan GCG dan pelaporan internal; dan14) rencana strategis Bank.

\section{Earning}

Penilaian berdasarkan kepada rentabilitas suatu bank yaitu melihat kemampuan suatu bank dalam menciptakan laba, bank perlu memperhatikan skala bisnis, karakteristik, dan/atau kompleksitas usaha bank serta ketersediaan data dan informasi yang dimiliki. Peneliti memakai NIM dan ROA dalam mengatur tingkat rentabilitas suatu bank. 


\section{Capital}

Penilaian atas faktor permodalan meliputi evaluasi terhadap kecukupan permodalan dan kecukupan pengelolaan permodalan. Dalam melakukan perhitungan permodalan, bank wajib mengacu pada ketentuan Bank Indonesia yang mengatur mengenai Kewajiban Penyediaan Modal Minimum bagi Bank Umum. Selain itu, dalam melakukan penilaian kecukupan permodalan, bank juga harus mengaitkan kecukupan modal dengan profil risiko bank.

\section{Kerangka Konseptual Pemikiran}

Kerangka Konseptual Pemikiran untuk mengukur tingkat kesehatan pada bank PT.Bank Muamalat Indonesia Tbk periode 2012 - 2016 dengan menggunakan metode RGEC adalah sebagai berikut:

\begin{tabular}{|c|c|}
\hline \multicolumn{2}{|c|}{$\begin{array}{c}\text { Laporan Keuangan Konsolidasi } \\
\text { PT.Bank Muamalat Indonesia Tbk } \\
\text { periode } 2012 \text { - } 2016\end{array}$} \\
\hline \multicolumn{2}{|r|}{$\frac{1}{t}$} \\
\hline \multicolumn{2}{|c|}{ Metode RGEC: } \\
\hline \multicolumn{2}{|c|}{ 1. Risk Profile } \\
\hline \multicolumn{2}{|c|}{ 2. Good Corporate Governance } \\
\hline \multicolumn{2}{|c|}{ 3. Earnings } \\
\hline \multicolumn{2}{|c|}{ 4. Capital (CAR) } \\
\hline \multicolumn{2}{|c|}{$\downarrow$} \\
\hline \multicolumn{2}{|c|}{ Tingkat Kesehatan Bank: } \\
\hline Peringkat 1 & : Sangat Sehat \\
\hline Peringkat 2 & : Sehat \\
\hline Peringkat 3 & : Cukup Sehat \\
\hline Peringkat 4 & : Kurang Sehat \\
\hline Peringkat 5 & : Tidak Sehat \\
\hline
\end{tabular}

Gambar 2.1 Kerangka Konseptual Pemikiran

\section{Metodologi Penelitian}

\subsection{Desain Penelitian}

Penelitian ini merupakan penelitian deskriptif yaitu suatu metode penelitian yang ditujukan untuk menggambarkan fenomena-fenomena yang berlangsung saat ini atau pada saat lampau. Penelitian ini akan dilakukan dengan mengumpulkan data-data sesuai dengan ketentuan yang telah diatur dalam Peraturan Bank Indonesia No. 13/1/PBI/2011 dan SE No. 13/ 24/ DPNP tanggal 25 Oktober 2011.

\subsection{Operasional Penelitian}

Peraturan tentang penilaian kesehatan bank terdapat pada Peraturan Bank Indonesia No. 13/1/PBI/2011 dan SE No. 13/ 24/ DPNP tanggal 25 Oktober 2011. Yang menjadi indikator adalah RGEC yang terdiri dari Risk atau risiko (R), Good Corporate Governance (GCG), Earnings (E), dan Capital (C) dan penilaian menggunakan skala 1 sampai 5 semakin kecil poin yang diterima itu menandakan kesehatan bank semakin baik. 


\subsection{Subjek dan Objek Penelitian}

Subjek dalam penelitian ini adalah PT.Bank Muamalat Indonesia Tbk. Objek penelitian ini adalah Laporan Keuangan publikasi PT. Bank Muamalat Indonesia Tbk periode 20122016.

\subsection{Jenis dan Sumber Data}

Jenis data yang digunakan dalam penelitian ini adalah data dokumenter. Data dokumenter adalah data penelitian antara lain berupa faktor, jurnal, surat -surat, hasil notulen,memo atau bentuk laporan program. Berdasarkan sumber data penelitian ini mneggunakan data sekunder. Data sekunder adalah sumber data penelitian yang diperoleh peneliti secara tidak langsung melalui media perantara. (Nur Indriantoro dan Supomo, 2013:147). Dalam penelitian ini data sekunder diperoleh dari Laporan Keuangan Publikasi periode tahun 2012-2016.

\subsection{Teknik Analisis Data}

Analisis tingkat kesehatan bank mengacu pada pedoman perhitungan yang diatur dalam Surat Edaran (SE) Bank Indoensia No. 13/24/DPNP tanggal 25 Oktober 2011 sedangkan penjelasan peringkat komposit diatur dalam Metode RGEC, Yaitu:

1.Risk Profile

1) Risiko Kredit

- Rasio kredit bermasalah (NPL)

$$
\text { NPL }=\frac{\text { Total Kredit bermasalah }}{\text { Total Kredit }}
$$

2) Risiko Pasar

- Posisi Devisa Neto (PDN)

$$
\text { PDN }=\frac{\text { Posisi Devisa Neto }}{\text { Total Modal }}
$$

3) Risiko Likuiditas

- Load On Depost Ratio (LDR)

Total Kredit yang diberikan

$$
\mathrm{LDR}=\frac{\text { Dana pihak ketiga }}{\text { Tot }}
$$




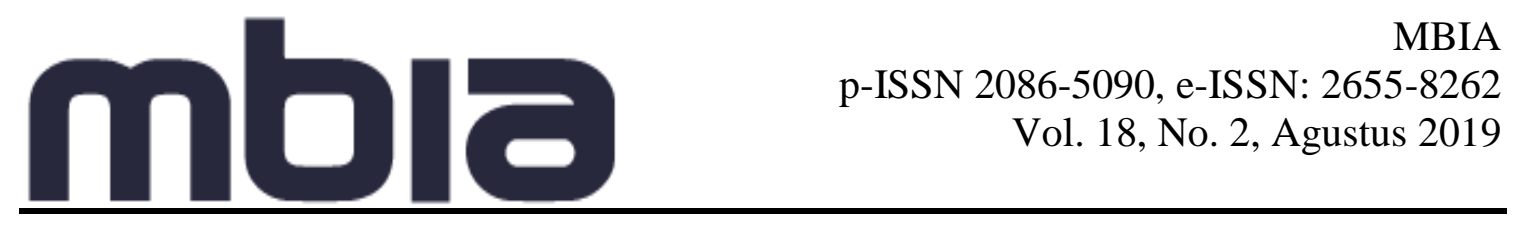

Tabel 3.1 : Parameter/Indikator untuk mengukur risiko Inheren

Risiko

Kredit

Pasar

Likuiditas

Operasional

Reputasi
Definisi

Risiko akibat kegagalan debitur dalam memenuhi kewajiban kepada bank

Risiko pada posisi neraca dan rekeing administrative termasuk transaksi rekening derivative. Akibat perubaha dari kondisi pasar

Risiko akibat ketidakmampuan bank untukp memenuhi kewajiban yang jatuh tempo dari sumber pendanaan arus kas dan dari aset likuid berkualitas tinggi yang dapat digunakan, tanpa mengganggu aktivitas dan kondisi keuangan bank.

Resiko akibat ketidakcukupan dan tidak berfungsinya proses internal, kesalahan manusia, kegagalan system, serta adanya kejadian eksternal yang mempengaruhi operasional bank.

Risiko yang timbul akibat bank tidak mematuhi dan tidak melaksanakan peraturan perundang-undangan dan ketentuan yang berlaku.

Risiko akibat menurunnya tingkat kepercayaan stakeholder yang bersumber dari persepsi negative terhadap bank
Parameter/Indikator

15 Indikator

(NPL)

17 Indikator (PDN)

11 Indikator (LDR)

15 Indikator (Internal Fraud)

5 Indikator (frekuensi pelanggaran karena tidak sesuai dengan standar yang berlaku umum)

10 indikator (frekuensi dan penyelesaian keluhan nasabah)

Sumber : SE BI No. 13/24/DPNP tanggal 25 Oktober 2011

Tabel 3.2 : Klasifikasi peringkat per risiko untuk mengukur risiko Inheren

\begin{tabular}{|c|c|c|c|c|c|c|}
\hline & Risiko kredit & Risiko Pasar & Risiko Likuiditas & Risiko Operasional & Risiko Kepatuhan & $\begin{array}{c}\text { Resiko } \\
\text { Reputasi }\end{array}$ \\
\hline Peringkat & NPL & PDN & LDR & Jumlah Fraud & $\begin{array}{c}\text { Frekuensi } \\
\text { ketidakpatuhan } \\
\text { terhadap ketentuan } \\
\text { yang berlaku } \\
\end{array}$ & $\begin{array}{c}\text { Penyelesaian } \\
\text { Pengaduan } \\
\text { Nasabah }\end{array}$ \\
\hline$\overline{11}$ & NPL $<3 \%$ & PDN $\leq 5 \%$ & $50<\mathrm{LDR} \leq 75 \%$ & Fraud $<1$ & Ketidakpatuhan $<3$ & $81 \%-100 \%$ \\
\hline 2 & $3 \% \leq \mathrm{NPL}<5 \%$ & $5 \%<\mathrm{PDN} \leq 10 \%$ & $75 \%<\mathrm{LDR} \leq 85 \%$ & $1 \leq$ Fraud $<5$ & $3 \leq$ ketidakpatuhan $<6$ & $61 \%-80 \%$ \\
\hline 3 & $5 \% \leq \mathrm{NPL}<8 \%$ & $10 \%<\mathrm{PDN} \leq 20 \%$ & $85 \%<\mathrm{LDR} \leq 100 \%$ & $5 \leq$ Fraud $<9$ & $3 \leq$ ketidakpatuhan $<6$ & $41 \%-60 \%$ \\
\hline 4 & $8 \% \leq \mathrm{NPL}<10 \%$ & $20 \%<\mathrm{PDN} \leq 25 \%$ & $1005 \%<\mathrm{LDR} \leq 120 \%$ & $9 \leq$ Fraud $<13$ & $3 \leq$ ketidakpatuhan $<6$ & $21 \%-40 \%$ \\
\hline 5 & $\mathrm{NPL} \geq 10 \%$ & $\mathrm{PDN}>25 \%$ & $\mathrm{LDR} \geq 210 \%$ & $13 \leq$ Fraud $<16$ & ketidakpatuhan $\geq 12$ & $0 \%-20 \%$ \\
\hline
\end{tabular}

Sumber: SE BI No. 6/21/DPNP tanggal 31 Mei 2004 (risiko kredit, risiko Pasar, dan risiko likuiditas) dan sekunder (risiko operasional, risiko kepatuhan, dan risiko reputasi.) 


\section{b.Penilaian Kualitas Penerapan Manajemen Risiko}

Tabel 3.3 : Klasifikasi skor dalam menilai penerapan manajemen risiko

\begin{tabular}{llc}
\hline \multicolumn{1}{c}{ Aspek } & Skor Maksimal \\
\hline 1 & Tata Kelola Risiko & 20 \\
2 & $\begin{array}{l}\text { Kerangka manajemen risiko } \\
3\end{array}$ & 30 \\
& $\begin{array}{l}\text { Proses manajemen risiko, kecukupan sumber daya } \\
\text { manusia, dan kecukupan sistem informasi } \\
\text { manajemen }\end{array}$ & 30 \\
4 & $\begin{array}{l}\text { Kecukupan sistem pengendalian risiko, dengan } \\
\text { memperhatikan karakteristik dan kompleksitas usaha } \\
\text { bank }\end{array}$ & 20 \\
Total Skor & 100 \\
\hline Sumber : Sekunder 2013
\end{tabular}

Tabel 3.4 : Klasifikasi Skor Risiko inheren dan sistem pengendalian risiko

\begin{tabular}{ccc}
\hline Keterangan & Skor & Peringkat/Predikat \\
\hline Risiko Inheren & $81-100$ & Low \\
& $61-80$ & Low Moderate \\
& $41-60$ & Moderate \\
& $21-40$ & Moderate-High \\
Sistem Pengendalian risiko & $0-20$ & High \\
& $81-100$ & Strong \\
& $61-80$ & Satisfacory \\
& $41-60$ & Fair \\
& $21-40$ & Marginal \\
& $0-20$ & Unsatisfactory
\end{tabular}

Sumber : Sekunder 2013

Tabel 3.5 : Matriks klasifikasi peringkat pada risk profile

\begin{tabular}{|l|c|c|c|c|c|}
\hline \multirow{2}{*}{ Risiko Inheren } & \multicolumn{6}{|c|}{ Kualitas Penerapan Manajemen Risiko } \\
\cline { 2 - 6 } & Strong & Satisfactory & Fair & Marginal & Unsatisfactory \\
\hline Low & 1 & 1 & 2 & 3 & 3 \\
\hline Low to Moderate & 1 & 2 & 2 & 3 & 4 \\
\hline Moderate & 2 & 2 & 3 & 4 & 4 \\
\hline Moderate to High & 2 & 3 & 4 & 4 & 5 \\
\hline High & 3 & 3 & 4 & 5 & 5 \\
\hline
\end{tabular}

Sumber : Surat Edaran Bank Indonesia Nomor 13/24/DPNP tanggal 25 Oktober 2011 


\section{Good Corporate Governance.}

Tabel 3.6 : Klasifikasi peringkat komposit Good Corporate Governance

\begin{tabular}{ccc}
\hline Peringkat & Nilai Komposit & Peringkat Komposit \\
\hline 1 & $<1.5$ & Sangat Baik \\
2 & $\geq 1.5-<2.5$ & Baik \\
3 & $\geq 2.5-<3.5$ & Cukup Baik \\
4 & $\geq 3.5-<4.5$ & Kurang Baik \\
5 & $\geq 4.5-<5.0$ & Tidak Baik \\
\hline
\end{tabular}

Sumber : SK BI Nomor 9/12/DPNP

\section{Earning}

Tabel 3.7 : Klasifikasi peringkat ROA dan NIM

\begin{tabular}{ccc}
\hline Peringkat & Rasio & \\
\hline 1 & ROA $>1,5 \%$ & NIM $>3 \%$ \\
2 & $1,25 \%<\mathrm{ROA} \leq 1,5 \%$ & $2 \%<\mathrm{NIM} \leq 3 \%$ \\
3 & $0,5 \%<\mathrm{ROA} \leq 1,25 \%$ & $1,5 \%<\mathrm{NIM} \leq 2 \%$ \\
4 & $0<\mathrm{ROA} \leq 0,5 \%$ & $1 \%<\mathrm{NIM} \leq 1,5 \%$ \\
5 & $\mathrm{ROA} \leq 1,5 \%$ & $\mathrm{NIM} \leq 1 \%$ \\
\hline
\end{tabular}

Sumber : SE BI No. 6/23/DPNP tanggal 31 Mei 2004

\section{Capital}

Tabel 3.8 : Klasifikasi peringkat CAR

\begin{tabular}{cc}
\hline Peringkat & Rasio \\
\hline 1 & CAR $\geq 12 \%$ \\
2 & $9 \% \leq \mathrm{CAR}<12 \%$ \\
3 & $8 \% \leq \mathrm{CAR}<9 \%$ \\
4 & $6 \% \leq \mathrm{CAR}<8 \%$ \\
5 & $\mathrm{CAR}<6 \%$ \\
Sumber : SE BI No. 6/23/DPNP tanggal 31 Mei 2004
\end{tabular}

Peringkat Tingkat Kesehatan Bank

Tabel 3.9 : Peringkat komposit tingkat kesehatan bank

\begin{tabular}{cc}
\hline Peringkat & Predikat \\
\hline 1 & Sangat Sehat \\
2 & Sehat \\
3 & Cukup Sehat \\
4 & Kurang sehat \\
5 & Tidak sehat \\
\end{tabular}




\section{Hasil dan Pembahasan}

\subsection{Risk Profile}

Faktor pertama dalam RGEC adalah Risk Profile. Berikut hasil penilaian dari 6 risiko yaitu Risiko Kredit, Pasar, Likuiditas, Operasional, Reputasi dan Kepatuhan dari $\quad$ PT. Bank Muamalat Indonesia Tbk pada tahun 2012 sampai dengan 2016.

Tabel 4.1 : Perhitungan skor Risk Profile PT.BMI Tbk Tahun 2012

\begin{tabular}{|l|l|l|l|l|l|l|l|l|l|l|}
\hline \multirow{2}{*}{$\begin{array}{l}\text { O } \\
\text { O }\end{array}$} & Jenis Risiko & \multicolumn{4}{|c|}{ Risiko Inheren } & \multicolumn{3}{|c|}{ Penerapan Manajemen Risiko } & Risiko Komposit \\
\cline { 2 - 12 } & Skor & Bobot & $\begin{array}{c}\text { Skor } \\
\text { X } \\
\text { Bobot }\end{array}$ & Tingkat Risiko & Skor & Bobot & $\begin{array}{c}\text { Skor } \\
\text { X } \\
\text { Bobot }\end{array}$ & Pengendalian & \\
\hline 1 & Kredit & 55 & $25 \%$ & 13,75 & Moderate & 80 & $25 \%$ & 20 & Satifactory & Low to moderate \\
\hline 2 & Pasar & 76 & $15 \%$ & 11,40 & Low Moderate & 70 & $15 \%$ & 10,5 & Satisfactory & Low to moderate \\
\hline 3 & Likuiditas & 78 & $18 \%$ & 14,04 & Low Moderate & 80 & $18 \%$ & 14,4 & Satisfactory & Low to moderate \\
\hline 4 & Operasional & 50 & $18 \%$ & 9 & Moderate & 80 & $18 \%$ & 14,4 & Satisfactory & Low to moderate \\
\hline 5 & Reputasi & 55 & $13 \%$ & 7,15 & Moderate & 80 & $13 \%$ & 10,4 & Satisfactory & Low to moderate \\
\hline 6 & Kepatuhan & 70 & $11 \%$ & 7,7 & Low Moderate & 80 & $11 \%$ & 8,8 & Satisfactory & Low to moderate \\
\hline \multicolumn{2}{l}{ Peringkat Risiko } & & $\mathbf{1 0 0 \%}$ & $\mathbf{6 3 , 0 4}$ & $\begin{array}{l}\text { Low } \\
\text { Moderate to }\end{array}$ & & $\mathbf{1 0 0 \%}$ & $\mathbf{7 8 , 5}$ & Satisfactory & Low to moderate \\
\hline
\end{tabular}

Tabel 4.2 Perhitungan skor Risk Profile PT.BMI Tbk Tahun 2013

\begin{tabular}{|l|l|l|l|l|l|l|l|l|l|l|}
\hline $\begin{array}{l}\text { N } \\
\text { O }\end{array}$ & Jenis Risiko & \multicolumn{4}{|c|}{ Risiko Inheren } & \multicolumn{3}{|c|}{ Penerapan Manajemen Risiko } & Risiko Komposit \\
\cline { 2 - 11 } & Skor & Bobot & $\begin{array}{c}\text { Skor } \\
\text { X } \\
\text { Bobot }\end{array}$ & Tingkat Risiko & Skor & Bobot & $\begin{array}{c}\text { Skor } \\
\text { X } \\
\text { Bobot }\end{array}$ & Pengendalian & \\
\hline 1 & Kredit & 70 & $25 \%$ & 17,5 & Low Moderate & 70 & $25 \%$ & 17,5 & Satisfactory & Low to moderate \\
\hline 2 & Pasar & 78 & $15 \%$ & 11,7 & Low Moderate & 70 & $15 \%$ & 10,5 & Satisfactory & Low to moderate \\
\hline 3 & Likuiditas & 76 & $18 \%$ & 13,68 & Low Moderate & 80 & $18 \%$ & 14,4 & Satisfactory & Low moderate \\
\hline 4 & Operasional & 68.3 & $18 \%$ & 12,29 & Low Moderate & 80 & $18 \%$ & 14,4 & Satisfactory & Low moderate \\
\hline 5 & Reputasi & 73 & $13 \%$ & 9,49 & Low Moderate & 70 & $13 \%$ & 9,1 & Satisfactory & Low moderate \\
\hline 6 & Kepatuhan & 67,8 & $11 \%$ & 7,45 & Low Moderate & 70 & $11 \%$ & 7,7 & Satisfactory & Low moderate \\
\hline Peringkat Risiko & & $\mathbf{1 0 0 \%}$ & $\mathbf{7 2 , 1 1}$ & Low Moderate & & $\mathbf{1 0 0 \%}$ & $\mathbf{7 3 , 6}$ & Satisfactory & Low to moderate \\
\hline
\end{tabular}

Tabel 4.3: Perhitungan skor Risk Profile PT.BMI Tbk Tahun 2014

\begin{tabular}{|l|l|l|l|l|l|l|l|l|l|l|}
\hline $\begin{array}{l}\text { N } \\
\text { O }\end{array}$ & Jenis Risiko & \multicolumn{4}{|c|}{ Risiko Inheren } & \multicolumn{3}{|c|}{ Penerapan Manajemen Risiko } & Risiko Komposit \\
\cline { 2 - 11 } & Skor & Bobot & $\begin{array}{c}\text { Skor } \\
\text { X } \\
\text { Bobot }\end{array}$ & Tingkat Risiko & Skor & Bobot & $\begin{array}{c}\text { Skor } \\
\text { X } \\
\text { Bobot }\end{array}$ & Pengendalian & \\
\hline 1 & Kredit & 60 & $25 \%$ & 15 & Moderate & 70 & $25 \%$ & 17,5 & Satisfactory & Low to moderate \\
\hline 2 & Pasar & 71,4 & $15 \%$ & 10,71 & Low Moderate & 70 & $15 \%$ & 10,5 & Satisfactory & Low to moderate \\
\hline 3 & Likuiditas & 72,5 & $18 \%$ & 13,05 & Low Moderate & 80 & $18 \%$ & 14,4 & Satisfactory & Low to moderate \\
\hline 4 & Operasional & 50 & $18 \%$ & 9 & Moderate & 70 & $18 \%$ & 12,6 & Satisfactory & Low to moderate \\
\hline 5 & Reputasi & 78 & $13 \%$ & 10,14 & Low Moderate & 70 & $13 \%$ & 9,1 & Satisfactory & Low to moderate \\
\hline 6 & Kepatuhan & 67 & $11 \%$ & 7,37 & Low Moderate & 80 & $11 \%$ & 8,8 & Satisfactory & Low moderate \\
\hline \multicolumn{2}{|l|}{ Peringkat Risiko } & & $\mathbf{1 0 0 \%}$ & $\mathbf{6 5 , 2 7}$ & $\begin{array}{l}\text { Low to } \\
\text { moderate }\end{array}$ & & $\mathbf{1 0 0 \%}$ & $\mathbf{7 2 , 9}$ & Satisfactory & Low moderate \\
\hline
\end{tabular}


Tabel 4.4 : Perhitungan skor Risk Profile PT.BMI Tbk Tahun 2015

\begin{tabular}{|l|l|l|l|l|l|l|l|l|l|l|}
\hline $\begin{array}{l}\text { N } \\
\text { O }\end{array}$ & Jenis Risiko & \multicolumn{3}{|c|}{ Risiko Inheren } & \multicolumn{5}{c|}{ Penerapan Manajemen Risiko } & Risiko Komposit \\
\cline { 2 - 11 } & Skor & Bobot & $\begin{array}{c}\text { Skor } \\
\text { X } \\
\text { Bobot }\end{array}$ & Tingkat Risiko & Skor & Bobot & $\begin{array}{c}\text { Skor } \\
\text { Bobot }\end{array}$ & Pengendalian & \\
\hline 1 & Kredit & 64 & $25 \%$ & 16 & Low Moderate & 70 & $25 \%$ & 17,5 & Satisfactory & Low to moderate \\
\hline 2 & Pasar & 67 & $15 \%$ & 10,05 & Low Moderate & 70 & $15 \%$ & 10,5 & Satisfactory & Low to moderate \\
\hline 3 & Likuiditas & 52 & $18 \%$ & 9,36 & Moderate & 80 & $18 \%$ & 14,4 & Satisfactory & Low to moderate \\
\hline 4 & Operasional & 55 & $18 \%$ & 9,9 & Moderate & 80 & $18 \%$ & 14,4 & Satisfactory & Low to moderate \\
\hline 5 & Reputasi & 78 & $13 \%$ & 10,14 & Low Moderate & 70 & $13 \%$ & 9,1 & Satisfactory & Low to moderate \\
\hline 6 & Kepatuhan & 70 & $11 \%$ & 7,7 & Low Moderate & 70 & $11 \%$ & 7,7 & Satisfactory & Low to moderate \\
\hline Peringkat Risiko & & $100 \%$ & 63,5 & $\begin{array}{l}\text { Low to } \\
\text { moderate }\end{array}$ & & $100 \%$ & 73,6 & Satisfactory & Low to moderate \\
\hline
\end{tabular}

Tabel 4.5 : Perhitungan skor Risk Profile PT.BMI Tbk Tahun 2016

\begin{tabular}{|l|l|l|l|l|l|l|l|l|l|l|}
\hline $\begin{array}{l}\text { N } \\
\text { O }\end{array}$ & Jenis Risiko & \multicolumn{4}{|c|}{ Risiko Inheren } & \multicolumn{3}{|c|}{ Penerapan Manajemen Risiko } & Risiko Komposit \\
\cline { 2 - 10 } & Skor & Bobot & $\begin{array}{c}\text { Skor } \\
\text { X } \\
\text { Bobot }\end{array}$ & Tingkat Risiko & Skor & Bobot & $\begin{array}{c}\text { Skor } \\
\text { X } \\
\text { Bobot }\end{array}$ & Pengendalian & \\
\hline 1 & Kredit & 58 & $25 \%$ & 16,24 & Moderate & 60 & $25 \%$ & 15 & Fair & Moderate \\
\hline 2 & Pasar & 60 & $15 \%$ & 9 & Moderate & 70 & $15 \%$ & 10,5 & Satisfactory & Low to Moderate \\
\hline 3 & Likuiditas & 71 & $18 \%$ & 12,78 & Low Moderate & 70 & $18 \%$ & 12,6 & Satisfactory & Low to moderate \\
\hline 4 & Operasional & 50 & $18 \%$ & 9 & Moderate & 70 & $18 \%$ & 12,6 & Satisfactory & Low to Moderate \\
\hline 5 & Reputasi & 80 & $13 \%$ & 10,4 & Low Moderate & 60 & $13 \%$ & 7,8 & Fair & Low to Moderate \\
\hline 6 & Kepatuhan & 62 & $11 \%$ & 6,82 & Low Moderate & 70 & $11 \%$ & 7,7 & Satisfactory & Low to moderate \\
\hline \multicolumn{2}{l|}{ Peringkat Risiko } & & $100 \%$ & 64,24 & $\begin{array}{l}\text { Low to } \\
\text { moderate }\end{array}$ & & $100 \%$ & 66,2 & Satisfactory & Low to moderate \\
\hline
\end{tabular}

Untuk penilaian Profil Risiko periode 2012-2016, risiko inheren PT.BMI Tbk Peneliti tidak dapat mencantumkan risiko hukum dan startejik karena kedua risiko tersebut sulit dalam mendapatkan data serta proses pengukuran dalam pemberian skor. Jadi, bobot kedua risiko tersebut dikalkulasi dalam enam risiko yang dapat diteliti.

\subsection{Good Coorporate Governance}

Faktor kedua dalam RGEC adalah Good Corporate Governance. Berikut ini adalah hasil dari penilaian faktor Good Corporate Governance yang bersumber dari laporan tahunan PT.BMI Tbk tahun 2012 sampai dengan 2016.

Tabel 4.8 : Penilaian Faktor Good Corporate Governance pada Tahun 2012

\begin{tabular}{|l|l|c|c|l|}
\hline No & Apek yang dinilai & $\begin{array}{l}\text { Bobot } \\
(\mathrm{B}) \%\end{array}$ & $\begin{array}{l}\text { Peringkat } \\
(\mathrm{P})\end{array}$ & $\begin{array}{l}\text { Nilai } \\
(\mathrm{BXP})\end{array}$ \\
\hline 1 & $\begin{array}{l}\text { Pelaksanaan Tugas dan Tanggung Jawab Dewan } \\
\text { Komisaris }\end{array}$ & 10 & 2 & 0,2 \\
\hline 2 & Pelaksanaan Tugas dan Tanggung Jawab Direksi & 20 & 2 & 0,4 \\
\hline 3 & Kelengkapan dan Pelaksanaan Tugas Komite & 10 & 3 & 0.3 \\
\hline 4 & Penanganan Benturan Kepentingan & 10 & 2 & 0,2 \\
\hline 5 & Penerapan Fungsi Kepatuhan perusahaan & 5 & 2 & 0,1 \\
\hline 6 & Penerapan Fungsi Audit intern & 5 & 3 & 0,15 \\
\hline 7 & Penerapan fungsi audit ekstern & 5 & 2 & 0,1 \\
\hline 8 & $\begin{array}{l}\text { Fungsi Manajemen risiko termasuk pengendalian } \\
\text { intern }\end{array}$ & 7.5 & 2 & 0,15 \\
\hline 9 & $\begin{array}{l}\text { Penyediaan dana kepada pihak terkait dan debitor } \\
\text { besar }\end{array}$ & 7.5 & 2 & 0,15 \\
\hline 10 & $\begin{array}{l}\text { Tranparansi kondisi keuangan dan non keuangan, } \\
\text { Laporan Pelaksanaan GCG dan pelaporan internal. }\end{array}$ & 15 & 2 & 0,3 \\
\hline 11 & Rencana Strategis Perusahaan & 5 & 2 & 0,1 \\
\hline & NILAI KOMPOSIT & & $\begin{array}{l}2.15 \\
\text { (BAIK) }\end{array}$ \\
\hline
\end{tabular}

Sumber: Laporan Tahunan PT.BMI Tbk tahun 2012 
Tabel 4.9 : Penilaian Faktor Good Corporate Governance pada Tahun 2013

\begin{tabular}{|l|l|c|c|l|}
\hline $\begin{array}{l}\mathrm{N} \\
\mathrm{o}\end{array}$ & Aspek yang dinilai & $\begin{array}{l}\text { Bobot } \\
(\mathrm{B}) \%\end{array}$ & $\begin{array}{l}\text { Peringkat } \\
(\mathrm{P})\end{array}$ & $\begin{array}{l}\text { Nilai } \\
(\mathrm{BXP})\end{array}$ \\
\hline 1 & $\begin{array}{l}\text { Pelaksanaan Tugas dan Tanggung Jawab Dewan } \\
\text { Komisaris }\end{array}$ & 10 & 2 & 0,1 \\
\hline 2 & Pelaksanaan Tugas dan Tanggung Jawab Direksi & 20 & 2 & 0,4 \\
\hline 3 & Kelengkapan dan Pelaksanaan Tugas Komite & 10 & 2 & 0,2 \\
\hline 4 & Penanganan Benturan Kepentingan & 10 & 2 & 0,2 \\
\hline 5 & Penerapan Fungsi Kepatuhan perusahaan & 5 & 2 & 0,1 \\
\hline 6 & Penerapan Fungsi Audit intern & 5 & 3 & 0,15 \\
\hline 7 & Penerapan fungsi audit ekstern & 5 & 3 & 0,15 \\
\hline 8 & $\begin{array}{l}\text { Fungsi Manajemen risiko termasuk pengendalian } \\
\text { intern }\end{array}$ & 7.5 & 2 & 0,15 \\
\hline 9 & $\begin{array}{l}\text { Penyediaan dana kepada pihak terkait dan debitor } \\
\text { besar }\end{array}$ & 7.5 & 2 & 0,15 \\
\hline 10 & $\begin{array}{l}\text { Tranparansi kondisi keuangan dan non keuangan, } \\
\text { Laporan Pelaksanaan GCG dan pelaporan internal. }\end{array}$ & 15 & 2 & 0,3 \\
\hline 11 & Rencana Strategis Perusahaan & 5 & 2 & 0,1 \\
\hline & NILAI KOMPOSIT & & 2 \\
(BAIK)
\end{tabular}

Sumber: Laporan Tahunan PT.BMI Tbk tahun 2013

Tabel 4.10 : Penilaian Faktor Good Corporate Governance pada Tahun 2014

\begin{tabular}{|l|l|c|c|c|}
\hline No & Aspek yang dinilai & $\begin{array}{l}\text { Bobot } \\
(\mathrm{B}) \%\end{array}$ & $\begin{array}{l}\text { Peringkat } \\
(\mathrm{P})\end{array}$ & $\begin{array}{l}\text { Nilai } \\
(\mathrm{BXP})\end{array}$ \\
\hline 1 & $\begin{array}{l}\text { Pelaksanaan Tugas dan Tanggung Jawab Dewan } \\
\text { Komisaris }\end{array}$ & 10 & 2 & 0,1 \\
\hline 2 & Pelaksanaan Tugas dan Tanggung Jawab Direksi & 20 & 2 & 0,4 \\
\hline 3 & Kelengkapan dan Pelaksanaan Tugas Komite & 10 & 2 & 0,2 \\
\hline 4 & Penanganan Benturan Kepentingan & 10 & 2 & 0,2 \\
\hline 5 & Penerapan Fungsi Kepatuhan perusahaan & 5 & 2 & 0,1 \\
\hline 6 & Penerapan Fungsi Audit intern & 5 & 3 & 0,15 \\
\hline 7 & Penerapan fungsi audit ekstern & 5 & 3 & 0,15 \\
\hline 8 & $\begin{array}{l}\text { Fungsi Manajemen risiko termasuk pengendalian } \\
\text { intern }\end{array}$ & 7.5 & 2 & 0,15 \\
\hline 9 & $\begin{array}{l}\text { Penyediaan dana kepada pihak terkait dan debitor } \\
\text { besar }\end{array}$ & 7.5 & 2 & 0,15 \\
\hline 10 & $\begin{array}{l}\text { Tranparansi kondisi keuangan dan non keuangan, } \\
\text { Laporan Pelaksanaan GCG dan pelaporan internal. }\end{array}$ & 15 & 3 & 0,45 \\
\hline 11 & Rencana Strategis Perusahaan & 5 & 2 & 0,1 \\
\hline & NILAI KOMPOSIT & & 2.15 \\
& (BAIK) \\
\hline
\end{tabular}

Sumber: Laporan Tahunan PT.BMI Tbk tahun 2014 
Tabel 4.11: Penilaian Faktor Good Corporate Governance pada Tahun 2015

\begin{tabular}{|l|l|c|c|c|}
\hline No & Aspek yang dinilai & $\begin{array}{l}\text { Bobot } \\
(\mathrm{B}) \%\end{array}$ & $\begin{array}{l}\text { Peringkat } \\
(\mathrm{P})\end{array}$ & $\begin{array}{l}\text { Nilai } \\
(\mathrm{BXP})\end{array}$ \\
\hline 1 & Pelaksanaan Tugas dan Tanggung Jawab Dewan Komisaris & 10 & 2 & 0,2 \\
\hline 2 & Pelaksanaan Tugas dan Tanggung Jawab Direksi & 20 & 2 & 0,4 \\
\hline 3 & Kelengkapan dan Pelaksanaan Tugas Komite & 10 & 2 & 0,2 \\
\hline 4 & Penanganan Benturan Kepentingan & 10 & 2 & 0,2 \\
\hline 5 & Penerapan Fungsi Kepatuhan perusahaan & 5 & 2 & 0,1 \\
\hline 6 & Penerapan Fungsi Audit intern & 5 & 3 & 0,15 \\
\hline 7 & Penerapan fungsi audit ekstern & 5 & 2 & 0,1 \\
\hline 8 & Fungsi Manajemen risiko termasuk pengendalian intern & 7.5 & 3 & 0.225 \\
\hline 9 & Penyediaan dana kepada pihak terkait dan debitor besar & 7.5 & 2 & 0,15 \\
\hline 10 & Tranparansi kondisi keuangan dan non keuangan, Laporan & 15 & 3 & 0,45 \\
\hline 11 & Pelaksanaan GCG dan pelaporan internal. & & & \\
\hline & Rencana Strategis Perusahaan & 5 & 2 & 0,1 \\
& NILAI KOMPOSIT & & & 2,275 \\
& & & & (BAIK) \\
\hline
\end{tabular}

Sumber: Laporan Tahunan PT.BMI Tbk tahun 2015

Tabel 4.12 : Penilaian Faktor Good Corporate Governance pada Tahun 2016

\begin{tabular}{|l|l|c|c|c|}
\hline No & Aspek yang dinilai & $\begin{array}{l}\text { Bobot } \\
(\mathrm{B}) \%\end{array}$ & $\begin{array}{l}\text { Peringkat } \\
(\mathrm{P})\end{array}$ & $\begin{array}{c}\text { Nilai } \\
(\mathrm{BXP})\end{array}$ \\
\hline 1 & $\begin{array}{l}\text { Pelaksanaan Tugas dan Tanggung Jawab Dewan } \\
\text { Komisaris }\end{array}$ & 10 & 2 & 0,1 \\
\hline 2 & Pelaksanaan Tugas dan Tanggung Jawab Direksi & 20 & 2 & 0,4 \\
\hline 3 & Kelengkapan dan Pelaksanaan Tugas Komite & 10 & 2 & 0,2 \\
\hline 4 & Penanganan Benturan Kepentingan & 10 & 3 & 0,3 \\
\hline 5 & Penerapan Fungsi Kepatuhan perusahaan & 5 & 3 & 0,15 \\
\hline 6 & Penerapan Fungsi Audit intern & 5 & 3 & 0,45 \\
\hline 7 & Penerapan fungsi audit ekstern & 5 & 2 & 0,1 \\
\hline 8 & $\begin{array}{l}\text { Fungsi Manajemen risiko termasuk pengendalian } \\
\text { intern }\end{array}$ & 7.5 & 3 & 0,225 \\
\hline 9 & $\begin{array}{l}\text { Penyediaan dana kepada pihak terkait dan debitor } \\
\text { besar }\end{array}$ & 7.5 & 2 & 0,15 \\
\hline 10 & $\begin{array}{l}\text { Tranparansi kondisi keuangan dan non keuangan }, \\
\text { Laporan Pelaksanaan GCG dan pelaporan internal. }\end{array}$ & 15 & 3 & 0,45 \\
\hline 11 & Rencana Strategis Perusahaan & 5 & 2 & 0,1 \\
\hline & $\begin{array}{l}\text { Nilai Komposit } \\
\end{array}$ & & & 2,625 \\
& & & BUKUP \\
& & & & \\
\hline
\end{tabular}

Sumber: Laporan Tahunan PT.BMI Tbk tahun 2016

Untuk penilaian faktor yang kedua dalam metode RGEC yaitu Good Corporate Governance. PT BMI Tbk memperoleh predikat Baik setiap tahunnya dari tahun 2012 sampai dengan 2015, namun pada tahun 2016 mendapat predikat Cukup Baik dengan nilai 2,625. Data diatas merupakan data yang bersumber dari Laporan Tahunan PT.BMI Tbk periode 2012-2016. Peneliti menggunakan data yang tersedia dilaporan tahunan karena peniliti tidak dapat melakukan penelitian tentang GCG secara langsung karena keterbatasan waktu dan data. Tata kelola perusahaan dalam PT.BMI Tbk menggambarkan predikat Baik dan Cukup Baik hal ini, membuktikan bahwa PT.BMI Tbk secara 
keseluruhan mempunyai kualitas manajemen yang baik dan PT.BMI Tbk berhasil melaksanakan GCG sesuai dengan prinsip-prinsip GCG yang berpedoman pada Ketentuan Bank Indonesia mengenai pelaksanaan GCG.

\subsection{Earning}

\section{ROA}

Tabel 4.13: Pemeringkatan ROA PT.BMI Tbk tahun 2012-2016

\begin{tabular}{|l|c|c|c|c|c|}
\hline & 2012 & 2013 & 2014 & 2015 & 2016 \\
\hline ROA & $1,54 \%$ & $0,50 \%$ & $0,17 \%$ & $0,20 \%$ & $0,22 \%$ \\
\hline Peringkat & 2 & 3 & 5 & 4 & 4 \\
\hline
\end{tabular}

Sumber: Laporan Tahunan PT.BMI Tbk periode tahun 2012-2016

Pada faktor ketiga dalam metode RGEC yaitu Earning (rentabilitas), dalam indikator penilaian rasio yang dipakai adalah Net Interest Margin (NIM) dan Return On Asset (ROA). Pada tabel pemeringkatan ROA PT.BMI Tbk selama periode tahun 2012-2017 terlihat bahwa kemampuan PT.BMI Tbk dalam mengelola Total Aset untuk mendapatkan Laba sebelum Pajak sangatlah tidak sehat. Hal ini terlihat selama tahun 2013 ada pada peringkat 3 (cukup sehat), tahun 2014 pada peringkat 5 (tidak sehat), tahun 2015 pada peringkat 4 (kurang sehat) dan tahun 2016 pada peringkat 4 (kurang sehat). Hanya pada tahun 2012 PT.BMI Tbk berada pada peringkat 2 (sehat). Hal ini menunjukkan selama periode tahun 2012-2016 manajemen PT.BMI Tbk belum bisa melaksanakan kwajibannya sebagai lembaga intermediasi.

\section{NIM}

Tabel 4.14: Pemeringkatan NIM PT.BMI Tbk tahun 2012-2016

\begin{tabular}{|l|c|c|c|c|c|}
\hline & 2012 & 2013 & 2014 & 2015 & 2016 \\
\hline NIM & $4,64 \%$ & $4,64 \%$ & $3,36 \%$ & $4,09 \%$ & $3,21 \%$ \\
\hline Peringkat & 1 & 1 & 1 & 1 & 1 \\
\hline
\end{tabular}

Sumber: Laporan Tahunan PT.BMI Tbk periode tahun 2012-2016

Rasio Net Interest Margin (NIM) dalam metode RGEC yaitu Earning adalah metode yang dipergunakan oleh Bank Indonesia untuk melihat kemampuan bank dalam mengelola aktiva produktifnya menghasilkan pendapatan bersih. Dari tabel diatas terlihat bahwa selama periode tahun 2012 sampai dengan 2016 PT.BMI Tbk dapat mengelola aktiva produktif nya, hal ini ditinjukkan oleh selama periode tersebut PT.BMI Tbk selalu berada dalam peringkat 1 (sangat sehat).

\subsection{Capital}

Tabel 4.15: Pemeringkatan Capital PT.BMI Tbk tahun 2012-2016

\begin{tabular}{|l|l|l|l|l|l|}
\hline & 2012 & 2013 & 2014 & 2015 & 2016 \\
\hline CAR & $11,57 \%$ & $14,05 \%$ & $13,91 \%$ & $12 \%$ & $12,74 \%$ \\
\hline Peringkat & 1 & 1 & 1 & 1 & 1 \\
\hline
\end{tabular}

Sumber: Laporan Tahunan PT.BMI Tbk periode tahun 2012-2016

Pada faktor keempat yaitu permodalan, indikator yang dipilih adalah CAR. Berdasarkan SE BI Nomor 26/2/BPPP mengatur bahwa kewajiban penyediaan minimum atau CAR diukur dari persentase tertentu terhadap Aktiva Tertimbang Menurut Risiko (ATMR) 
sebesar $8 \%$ dari ATMR. Pada tabel diatas dapat terlihat bahwa selama periode tahun 2012-2016 PT. BMI Tbk telah berhasil memelihara kecukupan modal yang dimilikinya untuk menunjang aktiva yang mengandung risiko.

Tabel 4.16:Rekapitulasi penilaian RGEC PT.Bank Muamalat Indonesia Tbk tahun 20122014

\begin{tabular}{|c|c|c|c|c|c|c|c|c|c|}
\hline \multirow{3}{*}{$\begin{array}{l}\text { Metode } \\
\text { RGEC }\end{array}$} & \multicolumn{9}{|c|}{ PT.Bank Muamalat Indonesia Tbk tahun 2012-2014 } \\
\hline & \multicolumn{3}{|c|}{2012} & \multicolumn{3}{|c|}{2013} & \multicolumn{3}{|c|}{2014} \\
\hline & $\begin{array}{c}\text { Peringk } \\
\text { at }(\mathrm{P})\end{array}$ & $\begin{array}{c}\text { Bobot } \\
\text { (B) }\end{array}$ & PXB & $\begin{array}{c}\text { Peringkat } \\
\text { (P) }\end{array}$ & $\begin{array}{l}\text { Bobot } \\
\text { (B) }\end{array}$ & PXB & $\begin{array}{l}\text { Peringkat } \\
\text { (P) }\end{array}$ & $\begin{array}{c}\text { Bobot } \\
\text { (B) }\end{array}$ & PXB \\
\hline $\begin{array}{l}\text { Risk } \\
\text { Profile }\end{array}$ & 2 & $25 \%$ & 0,5 & 2 & $25 \%$ & 0,5 & 3 & $25 \%$ & 0,75 \\
\hline GCG & 2 & $25 \%$ & 0,5 & 2 & $25 \%$ & 0,5 & 2 & $25 \%$ & 0,5 \\
\hline \multicolumn{10}{|l|}{ Earnings } \\
\hline ROA & 2 & $12,5 \%$ & 0,25 & 3 & $12,5 \%$ & 0,375 & 5 & $12,5 \%$ & 0,625 \\
\hline NIM & 1 & $12,5 \%$ & 0,125 & 1 & $12,5 \%$ & 0,125 & 1 & $12,5 \%$ & 0,125 \\
\hline \multicolumn{10}{|l|}{ Capital } \\
\hline CAR & 1 & $25 \%$ & 0,25 & 1 & $25 \%$ & 0,25 & 1 & $25 \%$ & 0,25 \\
\hline $\begin{array}{l}\text { Total } \\
\text { Peringkat }\end{array}$ & & $100 \%$ & 1,625 & & $100 \%$ & 1,75 & & $100 \%$ & 2,25 \\
\hline Predikat & \multicolumn{3}{|c|}{ Sangat sehat } & \multicolumn{3}{|c|}{ Sangat Sehat } & \multicolumn{3}{|c|}{ Sehat } \\
\hline
\end{tabular}

Tabel 4.17:Rekapitulasi penilaian RGEC PT.Bank Muamalat Indonesia Tbk tahun 20152016

\begin{tabular}{|l|c|c|c|c|c|c|}
\hline \multirow{2}{*}{ Metode RGEC } & \multicolumn{6}{|c|}{ PT.Bank Muamalat Indonesia Tbk 2015-2016 } \\
\cline { 2 - 7 } & \multicolumn{7}{|c|}{2015} & \multicolumn{3}{c|}{2016} \\
\cline { 2 - 7 } & $\begin{array}{c}\text { Peringkat } \\
(\mathrm{P})\end{array}$ & $\begin{array}{c}\text { Bobot } \\
(\mathrm{B})\end{array}$ & PXB & $\begin{array}{c}\text { Peringkat } \\
(\mathrm{P})\end{array}$ & Bobot (B) & PXB \\
\hline Risk Profile & 2 & $25 \%$ & 0,5 & 3 & $25 \%$ & 0,75 \\
\hline GCG & 2 & $25 \%$ & 0,5 & 3 & $25 \%$ & 0,75 \\
\hline Earnings & & & & & & \\
\hline ROA & 4 & $12,5 \%$ & 1 & 4 & $12,5 \%$ & 1 \\
\hline NIM & 1 & $12,5 \%$ & 0,125 & 1 & $12,5 \%$ & 0,125 \\
\hline CAPITAL & & & & & & \\
\hline CAR & 1 & $25 \%$ & 0,25 & 1 & $25 \%$ & 0,25 \\
\hline Total Peringkat & \multicolumn{7}{|c|}{$100 \%$} & 2,375 & & $100 \%$ & 2,875 \\
\hline Predikat & Sehat & & Sehat \\
\hline
\end{tabular}

Tabel 4.7 : Tingkat Kesehatan Metode RGEC PT.BMI Tbk tahun 2012-2016

\begin{tabular}{|l|l|l|l|l|l|}
\hline & $\mathbf{2 0 1 2}$ & $\mathbf{2 0 1 3}$ & $\mathbf{2 0 1 4}$ & $\mathbf{2 0 1 5}$ & $\mathbf{2 0 1 6}$ \\
\hline a.Risk Profile & Low to Moderate & Low to Moderate & Moderate & Low to Moderate & Moderate \\
\hline b.GCG & Baik & Baik & Baik & Baik & Cukup Baik \\
\hline c.ROA & Sehat & Cukup Sehat & Tidak Sehat & Kurang Sehat & Kurang Sehat \\
\hline d.NIM & Sangat Sehat & Sangat Sehat & Sangat Sehat & Sangat Sehat & Sangat Sehat \\
\hline e.CAR & Sangat Sehat & Sangat Sehat & Sangat Sehat & Sangat Sehat & Sangat Sehat \\
\hline
\end{tabular}

\section{Kesimpulan}

Berdasarkan penelitian dan hasil analisis yang telah dilakukan, maka peneliti dapat menyimpulkan hal-hal sebagai berikut:

1. Berdasarkan faktor Risk Profile yang penilaiannya terdiri dari penilaian risiko kredit dengan menggunakan rasio NPF menggambarkan pengelolaan risiko kredit PT.BMI Tbk yang telah dilaksanakan dengan baik, karena mulai dari tahun 2012 sampai dengan 2016 NPF PT.BMI Tbk mengalami penurunan walaupun pada tahun 2011 NPL BRI diatas 2\%. Namun hal tersebut masih membuat BRI dalam 
kategori bank yang sehat. Pada penilaian risiko pasar yang dihitung dengan rasio IRR, BRI masih dapat dikategorikan memiliki risiko kenaikan tingkat suku bunga yang rendah dan pada penilaian risiko likuiditas yang dihitung dengan rasio LDR, LAR dan Cash Ratio BRI menunjukkan bahwa BRI mendapatkan predikat yang baik walaupun tidak sangat baik dan hal tersebut membuktikan bahwa BRI memiliki profitabilitas yang baik terhadap pengembalian kembali dana pihak ketiga.

2. Penilaian yang dilakukan terhadap PT.Bank Muamalat Indonesia Tbk yang dinilai dengan faktor Earning menggunakan Return on Asset (ROA) dapat dikategorikan ke dalam bank yang tidak sehat. Hal ini terlihat selama tahun 2013 ada pada peringkat 3 (cukup sehat), tahun 2014 pada peringkat 5 (tidak sehat), tahun 2015 pada peringkat 4 (kurang sehat) dan tahun 2016 pada peringkat 4 (kurang sehat). Hanya pada tahun 2012 PT.BMI Tbk berada pada peringkat 2 (sehat). Hal ini menunjukkan selama periode tahun 2012-2016 manajemen PT.BMI Tbk belum bisa melaksanakan kewajibannya sebagai lembaga intermediasi.

3. Berdasarkan faktor Good Corporate Governance (GCG), PT.BMI Tbk pada tahun 2012 sampai dengan 2016 sudah memiliki dan menerapkan tata kelola perusahaan dengan Baik. PT.BMI Tbk telah menetapkan dan mengaplikasikan aspek-aspek penilaian terhadap factor GCG yang ditetapkan oleh Bank Indonesia.

4. Berdasarkan faktor Capital atau permodalan yang penilaiannya menggunakan rumus Capital Adequacy Ratio (CAR), PT.BMI Tbk pada tahun 2012 sampai dengan 2016 memiliki rasio CAR pada peringkat 1 (satu) ini menunjukkan bahwa PT.BMI Tbk mampu melakukan pengelolaan permodalan dengan sangat baik sesuai dengan karakteristik, skala usaha dan kompleksitas perusahaan. Disamping hal tersebut PT.BMI Tbk juga memiliki tingkat kecukupan modal yang baik atas pemenuhan kewajibannya dan dapat mengatasi kemungkinan terjadinya risiko.

5. Dari hasil penelitian diatas, tingkat kesehatan Bank Muamalat Indonesia Tbk periode 2012-2016 dengan metode RGEC pada umumnya ada pada peringkat Sehat dan Sangat Sehat.

Saran yang berikan penulis dalam penelitian ini adalah 1) Tingkat kesehatan suatu bank merupakan hal yang penting yang dapat membuat para stakeholder memberikan kepercayaan untuk menanamkan dananya kedalam bank tersebut. Dalam rangka meningkatkan tingkat kesehatannya, disarankan PT.BMI Tbk terus memperkuat kegiatan usahanya agar jumlah asset yang dimiliki semakin meningkat, jumlah penyaluran dana baik dalam bnetuk kredit maupun penempatan di bank lain semakin meningkat serta pendapatan operasional dan laba yang diperoleh untuk tahun -tahun berikutnya semakin meningkat, 2) Dalam penyaluran kredit untuk tahun tahun berikutnya, PT.BMI Tbk harus lebih berhati-hati dalam memilih nasabah agar tingkat kredit macet menurun dan sesuai dengan ketentuan dari Bank Indonesia. 3) Bagi peneliti selanjutnya sebaiknya lebih menambahkan indikator/parameter yang dipilih dalam perhitungan perfaktor sehingga dapat menghasilkan hasil yang lebih lengkap dan lebih baik dalam mendpatkan hasil penelitian mengenai tingkat kesehatan bank. 


\section{Daftar Pustaka}

Bank Indonesia.(2011). Tentang Penilaian Tingkat Kesehatan BankUmum Surat Edaran (SE) Bank Indonesia No.13/24/DPNP Tanggal 25 Oktober 2011. Jakarta. Bank Indonesia.

Bank Indonesia. (2006). tentang Pelaksanaan Good Corporate Governance. Peraturan Bank Indonesia No.8/4/PBI/2006 tanggal 5 Oktober 2006. Jakarta. Bank Indonesia.

Bank Muamalat Indonesia.(2017). Laporam Keaungan Publikasi 2016.

Dira Ayu Krisnawati. (2014). Analisis Faktor Penentu Profitabilitas Bank di Indonesia Dengan Metode Risk Based Bank Rating (Studi Pada Bank - Bank Umum Go Public di Indoensia Periode 2008 - 2013. Skripsi Publikasi. Universitas Dipenogoro.

Jakaratsatu.com.(2017). Kepemimpinan Tidak Layak, Bank Muamalat Kini Goyah, (diakses dari https://jakartasatu.com/2017/02/10/kepemimpinan-tidak-layak-bankmuamalat-kini-goyah tanggal 1 Juni 2017).

Kasmir. (2008). Bank dan Lembaga Keuangan Lainnya. Edisi Revisi. Jakarta. Rajagrafindo Persada.

Muhamad Ibadil. (2013). Analisis Pengaruh Risiko, Tingkat Efisiensi Dan Good Corporate Governance Terhadap Kinerja Keuangan Perbankan (Pendekatan Beberapa Komponen Metode Risk Based Bank Rating SEBI 13/24/DPNP/2011, Studi Kasus Pada Bank Umum yang Terdaftar di BEI Periode 2008- 2012). Skripsi Publikasi. Universitas Dipenogoro.

Nur Indriantoro dan Bambang Supomo. (2013). Metodologi Penelitian Bisnis. Yogyakarta :BPFE

Peraturan Bank Indonesia. (2011). tentang Tata Cara PenilaianKesehatan Bank Umum Peraturan Bank Indonesia Nomor 13/1/PBI/2011. Jakarta: Bank Indonesia.

Sigit Triandaru dan Totok Budi Santoso. 2008. Bank dan Lembaga Keuangan Lainnya. Jakarta: Salemba Empat.

Surat Edaran Bank Indonesia. (2011). Matriks PerhitunganAnalisis Komponen Faktor Analisis RGEC untuk Bank Umum.Surat Edaran Bank Indonesia No.13/24/DPNP tanggal 25 Oktober 2011,

Tribunnews.com. (2016). Ada Apa Dengan Bank Syariah? Bank Muamalat Tutup 7 Kantor Cabang Pembantu. (diakses dari http://medan.tribunnews.com/2016/10/25/bank-muamalat-tutup-7-kcp-di-sumut tanggal 1 Juni 2017).

Undang-undang. 1998. Undang-undang No. 10 Tahun 1998, tentang Perbankan.

Voaislam.com.(2017). Skandal Bank Muamalat(1): CEO Lemah, Bank Muamalat 'Rontok'?.Diakses dari http://www.voaislam.com/read/intelligent/2017/02/10/48819/skandal-bankmuamalat-1-ceo-lemah-rontok tanggal 1 Juni 2017)

Veithzel Rivai. 2005. Manajemen Sumber Daya Manusia Untuk Perusahaan.

\section{Copyright Disclaimer}

Copyright for this article is retained by the author(s), with first publication rights granted to the journal. 